\author{
Kamil K. Pilichiewicz* \\ Dział Naukowy Książnicy Podlaskiej im. Łukasza Górnickiego w Białymstoku \\ https://orcid.org/0000-0001-5589-6797
}

\title{
Recepcja twórczości Gałczyńskiego jako wyzwanie. Kazus Michała Głowińskiego
}

Streszczenie: Tematem niniejszego artykułu jest problem odbioru twórczości Konstantego Ildefonsa Gałczyńskiego zaprezentowany na przykładzie uwag krytycznych Michała Głowińskiego oraz innych badaczy i twórców literatury, w tym Kazimierza Wyki, Czesława Miłosza i Mieczysława Jastruna. Zastanawiam się, czym można wytłumaczyć różnice w recepcji poezji autora Zaczarowanej dorożki.

Słowa-klucze: Konstanty Ildefons Gałczyński, Michał Głowiński, Mieczysław Jastrun, krytyka, twórczość.

\section{Reception of Gałczyński's work as a challenge. Case of Michał Głowiński}

Summary: The subject of this article is the reception of the works of Konstanty Ildefons Gałczyński on the example of critical remarks of Michał Głowiński and other researchers and authors of literature, including Kazimierz Wyka, Czesław Miłosz and Mieczysław Jastrun. The author

\footnotetext{
* Kamil K. Pilichiewicz - dr nauk humanistycznych w zakresie literaturoznawstwa, kulturoznawca, pracownik Działu Naukowego Książnicy Podlaskiej im. Łukasza Górnickiego w Białymstoku. Stały współpracownik Uniwersytetu w Białymstoku; współredaktor naukowy publikacji: Uniwersytet XXI wieku: nauka i lokalność. Studia (Białystok, 2018).
} 
addresses the question of the differences in the reception of Gałczyński's poetry and how to explain them.

Key words: Konstanty Ildefons Gałczyński, Michał Głowiński, Mieczysław Jastrun, criticism, creativity.

Zestawienie dwóch tak ważnych dla literatury polskiej XX wieku osobowości, jakimi są pisarz Konstanty Ildefons Gałczyński i pisarz-badacz literatury Michał Głowiński, okazuje się zadaniem niełatwym. Wymaga ono mówienia o rzeczach wykraczających poza granicę zobiektywizowanej oceny twórczości, a dotyczących krytyki literackiej z uwzględnieniem szerszego, polityczno-ideowego kontekstu. Niniejszy artykuł dotyka tematu istoty twórczości literackiej, jej oceny stricte naukowej, jak i subiektywno-czytelniczej. Krytyczne podejście autora Stylów odbioru do twórczości Gałczyńskiego jest wstępem do dyskusji o charakterze zdecydowanie ogólniejszym.

Głowiński pisze o autorze Rozmowy lirycznej zaskakująco niewiele. Zaskakująco, bowiem jako badacza interesuje go wszak pisarstwo młodopolskie i wartościowe przejawy XX-wiecznej twórczości literackiej. Dziwić więc może fakt, że nie rozpisuje się on na temat oryginalnej poezji Gałczyńskiego. Na przykład zabrakło jej omówienia w oczywistym, zdawałoby się, miejscu, jakim jest choćby szkic Literackość muzyki - muzyczność literatury ${ }^{1}$. Można więc powściągliwość badacza w temacie dzieł tego konkretnego poety odczytać jako przejaw celowego dystansowania się, czy wręcz lekceważenia? Spróbujmy prześledzić charakter wybranych wypowiedzi Głowińskiego, gdzie interesujący nas temat znajduje swój wyraz.

1 M. Głowiński, Literackość muzyki - muzyczność literatury, [w:] tegoż, Prace wybrane, T. II: Narracje literackie i nieliterackie, Kraków 1997, s. 189-206. Głowiński, pisząc o muzyczności literatury, skupia się przede wszystkim na liryce młodopolskiej i skamandrytach z J. Iwaszkiewiczem na czele.

Zob. W. Ligęza, Muzyka jako święto w liryce Konstantego Ildefonsa Gatczyńskiego, [w:] Dzieło i życie Konstantego Ildefonsa Gałczyńskiego, t. 1, red. A. Kulawik, J. S. Ossowski, Kraków 2005, s. 89-103. 
Najczęściej poezja Gałczyńskiego występuje w funkcji ilustracyjno-egzemplifikacyjnej do opisów zagadnień i problemów w konkretnych modelach wypowiedzi literackiej². Głowiński nie ocenia, nie krytykuje, nie odnosi się do autora cytowanych fragmentów wprost; traktuje go jako jeden z wielu przykładów. W całej jego twórczości znajdziemy jednak wypowiedzi o zdecydowanie innym charakterze. Exempli causa, w Rytuale i demagogii Gałczyński obok między innymi Iwaszkiewicza wymieniany jest jako twórca panegiryków w socrealistycznym kontekście ${ }^{3}$. W innym „świadectwie odbioru”4, w poświęconej poezji Bolesława Leśmiana książce Zaświat przedstawiony, szkicu Stowo i pieśń, lirykę Gałczyńskiego określa się zwrotem „poetycka rupieciarnia”’

W prozie wspomnieniowej Głowińskiego nie ma o autorze Niobe mowy. W opowieści autobiograficznej Kręgi obcości pojawia się lapidarna uwaga, wypowiedziana przy okazji snucia refleksji o muzyce:

Z jakichś powodów sięgnąć musiałem po któryś z roczników „Prosto z Mostu”. Mierziły mnie skrajnie prawicowe, bliskie nazizmowi teksty, wypełniające ten tygodnik (z pogromowymi wierszami Gałczyńskiego włącznie), z przyjemnością zaś przeglądałem reprezentujące inny świat recenzje muzyczne Konstantego Regameya, wolne od wszelkiej ideologii; w nich nawet żydowscy artyści (na przykład Rubinstein) obdarzani byli dobrym słowem ${ }^{6}$.

2 Zob. M. Głowiński, A. Okopień-Sławińska, J. Sławiński, Zarys teorii literatury, Warszawa 1975, s. 153: „Takie kształtowanie fonicznej warstwy utworu [chodzi o utwór Gałczyńskiego Ej, po szerokiej drodze - przyp. K.K.P.] ma w danym wypadku ścisły związek z jego liryczno-pieśniowym charakterem. Obce jest natomiast satyrycznym i dialogowym utworom Gałczyńskiego". Należy przy tym zaznaczyć, że autorowi Nowomowy po polsku, cytującemu fragmenty utworów literackich, zdarza się (czasami umyślnie) nie podawać ich autorów, zob. np. M. Głowiński, Literatura wobec nowomowy, [w:] tegoż, Prace wybrane, tom II, dz. cyt., s. 252 .

3 Tenże, Rytuat i demagogia. Trzynaście szkiców o sztuce zdegradowanej, Warszawa 1992, s. 112-113.

4 Zwrot Głowińskiego; zob. tenże, Style odbioru. Szkice o komunikacji literackiej, Kraków 1977, s. 117.

5 Tenże, Stowo i pieśń (Leśmiana poezja o poezji), [w:] tegoż, Zaświat przedstawiony. Szkice o poezji Bolestawa Leśmiana, Warszawa 1981, s. 51.

6 Tenże, Kręgi obcości. Opowieść autobiograficzna, Kraków 2010, s. 490. 
Nazwisko poety pojawia się mimochodem, zamknięte w nawiasie. Autor, pisząc o „pogromowych wierszach”, ma na myśli choćby niechlubny list $D o$

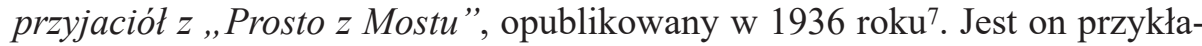
dem poparcia opcji polityczno-ideowej pisma, zawiera wulgarne treści antysemickie, skierowane przede wszystkim pod adresem środowiska „Wiadomości Literackich”. By dać inny przykład: w rozmowie-rzece z Grzegorzem Wołowcem autor Gier powieściowych również wypowiada się o Gałczyńskim w oględny sposób, nazywając poetą, którego „raczej nie ceni”»

W tytule mojego artykułu wymieniam dwie postacie centralne. Należałoby jednak przywołać tutaj również głosy pisarzy i badaczy współczesnych Głowińskiemu: Czesława Miłosza, Kazimierza Wykę i Mieczysława Jastruna, aby stworzyć swoisty punkt odniesienia dla moich rozważań, pozwalający naświetlić aspekty zastanawiającej niechęci Głowińskiego do poezji Gałczyńskiego.

To Wyka w 1938 roku, w przededniu wojny, zanotował między innymi takie słowa:

Gałczyński wzrusza się. Wzruszać pragnie czytelnika. Dba, ażeby czytelnikowi były wiadome osobiste przyczyny jego wzruszeń - żona, kot Salomon, kominek, pokój poety, Wilno. Śmiało z siebie samego czyni podmiot liryczny utworów. Jak preromantyk opiewa elegijnie i drwiąco - gdyby naturalnie istniała wówczas cyganeria - swój wyjazd z Warszawy. Nie boi się wezwania na pomoc bardzo umownych rekwizytów: aniołów stróżów, srebrzystości, niebieskości, szafirów, lazurów, szkarłatów, gwiazd, kadzidła. A jednak pod jego piórem szych staje się złotem, gwiazdy jak race rozpękają ładunkami najczystszego liryzmu. Jakaś niesamowita, niewytłumaczalna siła wzruszeń nasyca tę poezję?.

Poezję Gałczyńskiego Wyka nazywa „fantazyjną igraszką słów”10, „infantylną fantastyką słowną"11, samego twórcę , uzdolnionym, prawdziwym cyga-

7 Zob. K. I. Gałczyński, Do Przyjaciót z „Prosto z Mostu”, „Prosto z Mostu” 1936, nr 21.

8 M. Głowiński, G. Wołowiec, Czas nieprzewidziany. Dluga rozprawa bez pana, wójta i plebana, Warszawa 2018, s. 109.

9 K. Wyka, Poeta i partyjnictwo, [w:] tegoż, Rzecz wyobraźni, Warszawa 1977, s. 73.

10 Tamże, s. 73.

11 Tamże, s. 74-75. 
nem (od »cyganeria«) poezji polskiej” ${ }^{12}$, „wspaniałym i samotnym zabytkiem minionych formacji literackich"13.

Co natomiast o Gałczyńskim pisał główny jego oponent, Czesław Miłosz? W Zniewolonym umyśle poetę ukrył on pod pseudonimem Delta, określając go takimi terminami jak błazen, szarlatan, alkoholik. Wymienia ponadto skrupulatnie liczne jego przywary, ale jedno przyznać uczciwie musi - Delta to wybitny i tragiczny poeta ${ }^{14}$. W innym fragmencie pojawia się takie stwierdzenie:

Tematyka poezji Delty była przygnębiająca. A jednak poezja jego - tu jeszcze jedna z wewnętrznych sprzeczności tego fenomenu - wolna była od smutku i rozpaczy. Przeciwnie, biła z niej potężna afirmacja życia. Każdym swoim słowem Delta pochwalał świat taki, jakim go widział: kłębowisko absurdalnych zabaw, dążeń, słów i walk. Kochał swoją fantasmagorię. Kochał karuzele, tańczące Cyganki, statki na Wiśle wypełnione tłumem w niedzielne ranki, żonę, do której pisał ody, koty śpiące na parapetach, kwitnące jabłonie. Był zwolennikiem entuzjazmu i radości samych w sobie, czegokolwiek dotknął, zmieniało się w widowisko pełne ruchu, barw i muzyki ${ }^{15}$.

Wyka i Miłosz, mimo punktowania przywar autora Zaczarowanej dorożki, nie odmawiają mu talentu. Choć twierdzą - to przypadek Miłosza - że Gałczyński używa swojej twórczości (Poemat dla zdrajcy) jako broni propagandowej, doceniają jego twórczość sensu largo. Przypomnijmy, Miłosz to jeden z najbardziej cenionych przez Głowińskiego pisarzy ${ }^{16}$, a Wyka jest dlań niezaprzeczalnym naukowym autorytetem ${ }^{17}$. Owszem, nie oznacza to, że Głowiński powinien powielać ich sądy o Gałczyńskim, jednak jego wyraźnie pod tym względem odmienne zdanie może zastanawiać.

Mieczysław Jastrun w swym dzienniku, notatce z 30 lipca 1955 roku, opowiada:

12 Tamże, s. 75.

13 Tamże.

14 Cz. Miłosz, Zniewolony umyst, Kraków 1999, s. 198.

15 Tamże, s. 199.

16 Zob. M. Głowiński, Skrzydła i pięta, Kraków 2004, s. 154.

17 Zob. szkic Mój Kraków, [w:] tamże, s. 231-240. 
Rozmawiamy [z Julianem Przybosiem - przyp. K.P.] o Gałczyńskim, którego tom satyr leży na stole. Julian, oczywiście, źle mówi o tej poezji. Nie ma racji, mimo że jestem gotów przyznać, że popularność tej twórczości jest podejrzanego gatunku. Reprezentował on typ nowego inteligenta polskiego z jego pijacką wyobraźnią, z nihilizmem, połączonym ze skłonnością do ciągłej szarży. Ani jednej myśli. Ciągła opera buffo. Faszyzm - dobrze, socjalizm - klawo itd. ${ }^{18}$

We wpisie z 1 maja 1956 roku już zdecydowanie mniej dyplomatycznie stwierdza: „Tajemnica popularności Gałczyńskiego - przeciętność”19. Kilkanaście dni później (18 maja) potwierdza wcześniejszą ocenę: „W istocie Stawar jest pozytywistą. Co go pociąga w Gałczyńskim? Chyba nie alkohol? Więc co? Pospolitość polska, pospolitość drobnomieszczańska, kołtuńska"20. Jastruna niechęć do poezji autora Wita Stwosza uwidacznia się głównie w analizie recepcji i niedwuznacznych komentarzach pod adresem jej czytelników. Oto 17 czerwca 1961 roku krytyk stwierdza:

Jest jakaś fascynacja wierszami Gałczyńskiego u pewnych ludzi. Wiersze te działają na nich jak muzyka narodowa, jak poezja Wyspiańskiego, na wskroś irracjonalnie. Dla mnie irracjonalizm tej poezji (tak pozornie „racjonalnej”) jest podejrzany.

I jak jeszcze! czysta esencja ONR. Sama energia, dynamika nicości²1.

W innym miejscu Jastrun notuje myśl podobną: ,[...] wiem, że nie umiem pisać wierszy, które by się podobały (i nie chcę). Rozumieją Gałczyńskiego i Małgorzatę Hillar, nic lub prawie nic poza tym. Czy chciałbym mieć takich czytelników? Nie, lepiej - nikogo!'”22. We wpisie datowanym na 19 stycznia 1959 roku, będącym komentarzem do artykułu Andrzeja Stawara o Gałczyńskim $^{23}$, wyznaje:

M. Jastrun, Dziennik 1955-1981, Kraków 2002, s. 29.

19 Tamże, s. 48.

20 Tamże, s. 52.

21 Tamże, s. 304.

22 Tamże, s. 404.

23 Zob. A. Stawar, Gatczyński-kryzys piękna, „Polityka” 1959, nr 3. 
Mogę czytać o Gałczyńskim, nie mogę czytać tego poety. Obcy mi intelekt, obca wyobraźnia, to, co jest najmniej przyjemnego w charakterze nowoczesnych inteligentów - w nim uosobione.

Pijaństwo ducha - jakby powiedzieli romantycy. Ale to raczej komplement ${ }^{24}$.

Jastrun ocenia poezję Gałczyńskiego jako przeciętną, pospolitą, nowoczesną w pejoratywnym znaczeniu tego terminu. Nie buduje szczegółowej analizy, przytacza przy różnych okazjach jedynie opinie i ogólniki. Na tle tychże notatek wyróżnia się uwaga zanotowana 29 lipca 1960 roku, będąca jednocześnie komentarzem do artykułu o Gałczyńskim autorstwa Władysława Bieńkowskiego 25 :

[...] „Największy poeta XX wieku”. A więc nie Rilke, nie Supervielle, nie Valéry... lecz nasz swojski Gałczyński. Adoracja tego poety staje się dla mnie coraz jaśniejsza.

[...] Gałczyński to świętość narodowa, w tym sensie, w jakim czczono Wyspiańskiego.

Wyraz podświadomości inteligenta polskiego w naszych latach. Nie bagatela. ONR u spodu. [...]

Jakaś cząstka tajemnicy narodowej niedostępnej dla ludzi „nieczystego pochodzenia". A tu chodzi o rzecz inną. Po prostu są ludzie w Polsce, którym ta formacja psychiczna jest obca, której nie lubią. Znam takich. Komuniści, którzy lubią przechwytywać nastroje ogólne, zorientowali się, lecz trochę późno. I to ciekawe: to sąsiedztwo ONR z Partią Komunistyczną (o czym pisał Miłosz).

Najbardziej zdumiewa fakt, że Gałczyńskiemu przebaczono wiersze stalinowskie [...]. To wszystko - podejrzewa się niezupełnie słusznie - kpina, żart błazna. Tymczasem Gałczyński pisał o tym z powagą, był nie tyle żywiołem, ile oparem pijackim, był wyobraźnią z różnych, różnej wartości - kruszców. [...].

Zaczynam czytać Gałczyńskiego i odrzuca mnie, nie tyle nawet poetyka, ile zawartość psychiczna. Błazeństwo może być wartością, ale w imię czego, przeciw czemu. Nikt nie wie. Mgła.

24 M. Jastrun, Dziennik 1955-1981, dz. cyt., s. 181.

25 W. Bieńkowski, O K. I. Gałczyńskim: wspomnienia i refleksje, „Przegląd Kulturalny” 1960, nr 31. O Gałczyńskim pisze Bieńkowski także [w:] Wspomnienia o K. I. Gałczyńskim, przedm. i red. A. Kamieńska, J. Śpiewak, Warszawa 1961. 
[...] To, co odpycha: wdzięk łobuza, mizdrzenie się ciągłe i nachalne. [...] Żywiołowy? Tak, jest w tej poezji coś napastliwego, bojówka słów, które uderzają, ale czym? Mandolinami obwieszonymi różnymi wstążeczkami, różowymi, niebieskimi $^{26}$.

Ostatnie zdania cytowanego fragmentu przywodzą na myśl określenie autorstwa Głowińskiego: ,poetycka rupieciarnia”. W podejściu do „Zielonego Konstantego" jest więcej podobieństw między dwoma jego zdecydowanymi krytykami. Obaj - Jastrun i Głowiński - skupiają się na antysemickim wydźwięku tej twórczości, ideologicznej bliskości z ONR-em. Dla obu literatów są to kwestie w biografii Gałczyńskiego najważniejsze, mające przyćmić jego późniejszy dorobek artystyczny.

W Zarysie teorii literatury, którego Głowiński jest współautorem, możemy przeczytać:

Odbiorca, odczytując utwór, dopełnia go niejako, konfrontuje z własnymi doświadczeniami życiowymi, przestawia elementy w ramach dzieła i wnosi w jego obręb elementy nowe ${ }^{27}$.

Przypomnijmy - Jastrun i Głowiński są Polakami pochodzenia żydowskiego, mogą zatem być szczególnie wyczuleni na treści antysemickie. Ich krytyczna ocena poezji Gałczyńskiego zastanawia, gdy popatrzymy na nią jako na wynik „czysto” naukowej analizy. Inaczej jednak sprawa ta wygląda, gdy ideowo-polityczną część twórczości autora Listów z fiołkiem skonfrontować z determinującymi zainteresowania badawcze Głowińskiego kolejami jego życia. Przywołajmy garść faktów: badacz ma pochodzenie żydowskie, został ocalony w czasach Zagłady, a osiągnąwszy dojrzałość naukową podjął badania nad mową nienawiści i językiem propagandy w Polsce Ludowejej ${ }^{28}$ W swej

26 M. Jastrun, Dziennik 1955-1981, dz. cyt., s. 263-264.

27 M. Głowiński, A. Okopień-Sławińska, J. Sławiński, Zarys teorii literatury, dz. cyt., Warszawa 1975, s. 17.

28 Zob. prace M. Głowińskiego: Nowomowa po polsku, Warszawa 1990; Marcowe gadanie. Komentarze do stów 1966-1971, Warszawa 1991; Peereliada. Komentarze do stów 1976-1981, Warszawa 1993; Pismak 1863 i inne szkice o różnych brzydkich rzeczach, Warszawa 1995; Końcówka (czerwiec 1985 - styczeń 1989), Kraków 1999; Zła mowa, Warszawa 
pracy podkreśla przede wszystkim społeczną wymowę dzieła literackiego jako swoistego aktu komunikacji ${ }^{29}$. Gałczyńskiego, o czym pisałem, ocenia przede wszystkim przez pryzmat listu Do przyjaciót z „Prosto z Mostu”, Poematu dla zdrajcy, panegiryku Umart Stalin, współpracy poety z tygodnikami „Prosto z Mostu” i „Przekrój”. Mając na uwadze wszystkie te informacje, niechęć Głowińskiego - jako człowieka z „krwi i kości”, a nie zdepersonalizowanego badacza teorii literatury - przestaje być sprawą tak tajemniczą, jak się na początku zdawało.

Nie bez znaczenia pozostaje również fakt, że w roku śmierci Gałczyńskiego Głowiński (rocznik '34) nie ma jeszcze skończonych lat dwudziestu. Pozostaje za to w bliskich kontaktach z oponentami poety (w tym ze wspomnianym Jastrunem $^{30}$ ). Paradoksalnie, w tym konkretnym przypadku dystans czasowy nie musi działać na korzyść obiektywnego spojrzenia na badany materiał literacki. Nie znając bezpośrednio twórcy, młody naukowiec może być podatny na opinie tych, którzy takiego przywileju dostąpili. Trudno wówczas wyrobić w sobie dystans, tym bardziej w kontekście tak kontrowersyjnego poety, jak Gałczyński. Badacze literatury oraz literaci, którzy mieli osobisty kontakt $\mathrm{z}$ autorem Niobe, przedstawiają go dość często w korzystnym świetle. Warto jako przykład przywołać w tym miejscu choćby uwagi Ryszarda Matuszewskiego $^{31}$, który w artykule Mistrz pur-nonsensu wspomina:

Choć na uroki poezji Gałczyńskiego wrażliwy byłem zawsze, to jednak przez moich kolegów z łódzkiej „Kuźnicy”, z którą byłem wtedy związany, Gałczyński, również ten w nowym, powojennym wcieleniu, był traktowany raczej nieufnie. Pamiętano mu niektóre, nigdy później nieprzedrukowane, antysemickie wiersze z przedwojennego "Prosto z Mostu” i raczej gorszono się jego beztroskim akcesem do nowej rzeczywistości, niż go akceptowano. Dodajmy, że poetom „Kuźnicy", Jastrunowi czy Ważykowi, traktującym ówczesne przeobrażenia polityczne

2016; Rytuat i demagogia. Trzynaście szkiców o sztuce zdegradowanej, Warszawa 1992 oraz Inspiratorzy. Spiskowa kategoryzacja świata w okresie marcowym, „Teksty Drugie” 2000, nr 1-2, s. 75-84.

29 Zob. tenże, Style odbioru..., dz. cyt.; Zarys teorii literatury, dz. cyt.

30 M. Jastrun wspomina o młodym Głowińskim chociażby w cytowanym już dzienniku (s. 305).

31 Wskazanie na Matuszewskiego zawdzięczam prof. Zbigniewowi Chojnowskiemu. 
z całą powagą, zupełnie nie odpowiadał ludyczny ton tekstów mistrza Ildefonsa. Jeśli dodać do tego wszystkie, tak prawdziwe, jak zmyślone, historie na temat jego szaleństw, zarówno tych poalkoholowych, jak wynikłych po prostu z jego poetyckiej natury, zacierającej granice pomiędzy rzeczywistością a fantazją, moje zetknięcie się z Gałczyńskim żywym było pewnym zaskoczeniem ${ }^{32}$.

Matuszewski neutralizuje utarte informacje o Gałczyńskim (alkoholizm), z sentymentem wspomina o „poecie-trubadurze”33, „szalonym Kostku”, który swym humorem, wdziękiem i bezpośredniością potrafił rozbawić domowników Matuszewskiego ${ }^{34}$. Dużo starszy od autora Zaczarowanej dorożki Leopold Staff zadedykował mu wiersz (Gałczyński ${ }^{35}$ ):

Pokazałeś w wesołej herezji

Przez swe fraszki fiołkowe i gęsie,

lle jest nonsensu w poezji

I ile poezji w nonsensie.

W zbiorach Muzeum im. K. I. Gałczyńskiego w Praniu znaleźć można tomik Mazowsze i inne wiersze Władysława Broniewskiego z dedykacją: „Kochanemu poecie, i naprawdę poecie, K. I. Gałczyńskiemu”. Dodajmy, że nawet Jastrun, krytycznej oceny poezji autora Niobe, przyznaje to, czego Głowiński przyznać nie chce: „Czy to jest wybitny poeta? Myślę, że tak, mimo wszystko. Ale »wybitność« to chyba nie wszystko. Talent, ale do czego? - zapytywał już Irzykowski”36.

Wszystkie przywołane opinie, uwagi, wspomnienia, dedykacje skłaniają do zastanowienia się nad kwestiami odbioru twórczości literackiej ${ }^{37}$ i zadania znanych, obiegowych, choć jakże istotnych w tym kontekście pytań:

32 R. Matuszewski, Mistrz pur-nonsensu, ,Rocznik Towarzystwa Literackiego im. Adama Mickiewicza” 2003, nr 38, s. 32.

33 Tamże, s. 33.

34 Tamże, s. 32.

35 Zob. L. Staff, Gałczyński, [w:] Wspomnienia o K. I. Gałczyńskim, dz. cyt., s. 616.

36 M. Jastrun, dz. cyt., s. 264.

37 O szeroko pojętych problemach recepcji literackiej zob. Problemy odbioru i odbiorcy. Studia, red. T. Bujnicki, J. Sławiński, Wrocław 1977; J. Sławiński, O dzisiejszych normach czytania (znawców), „Teksty Drugie” 1974, nr 3, s. 9-32; H. Markiewicz, Odbiór i odbior- 
- Czy na podstawie jednego lub nawet kilku utworów stanowiących mały wycinek dorobku artystycznego można oceniać całą twórczość literacką jednego pisarza?

- Czy biografia pisarza, jego postępowanie, zachowanie w rzeczywistości pozaliterackiej powinny determinować całkowitą ocenę jego twórczości?

- Gdzie jest granica między oceną subiektywną a obiektywną i czy ona w ogóle istnieje?

Na ostatnie pytanie być może nigdy nie uzyskamy zadowalającej odpowiedzi. Na dwa pierwsze zdaje się Głowiński swoją postawą wobec Gałczyńskiego pośrednio odpowiadać w sposób twierdzący. Przy czym możemy założyć, że literaturoznawca pokroju profesora Michała Głowińskiego zna cały dorobek poety. Tym bardziej zasadną wydaje się zatem hipoteza, iż doświadczenie osobiste badacza, determinujące konkretne wybory naukowe/zawodowe, czyniło ocenę dzieła literackiego bardziej subiektywną niż chłodną, pozbawioną ładunku emocjonalnego, zmierzającą ku obiektywności analizy naukowej38.

Jeżeli zaakceptować owe założenia, wyartykułowana na wstępie niniejszego artykułu, zagadka nie znajduje jeszcze swego rozwikłania. Bo chociaż znikoma obecność twórczości Gałczyńskiego w analizach Głowińskiego może być odczytana jako wyraz jej lekceważenia, a nieliczne komentarze wskazują na niechęć wobec poety, to jednak brakuje w wypowiedziach badacza syntetycznej, krytycznej analizy twórczości Gałczyńskiego. Analizy, dodajmy,

ca $w$ badaniach literackich. Perspektywy i trudności, „Ruch Literacki” 1979, z. 1, s. 1-15; A. Kłoskowska, Potoczny odbiór literatury na przykładzie utworów Żeromskiego, „Pamiętnik Literacki” 1976, z. 1, s. 65-91; M. Naumann, Literatura i problem jej recepcji, przeł. K. Krzemieniowa, „Pamiętnik Literacki” 1980, z. 1, s. 281-300; K. Chmielewska, Ukryte założenia i aporie teorii recepcji, „Pamiętnik Literacki” 2001, z. 4, s. 5-27; Sporne i bezsporne problemy wiedzy o literaturze, red. W. Bolecki, R. Nycz, Warszawa 2002; A. Jarmuszkiewicz, Wspótczesne badania nad recepcją literacka w kontekście literatury światowej oraz pamięci kulturowej, [w:] Mapy świata - mapy ciała. Geografia i cielesność w literaturze, red. A. Jastrzębska, Kraków 2014. Wymieniłem jedynie mały fragment ogromnej literatury poświęconej temu zagadnieniu. Nie można zapominać, jak ważny wkład w badania nad odbiorem dzieła literackiego wniósł sam Głowiński klasyczną już publikacją Style odbioru. Szkice o komunikacji literackiej (Kraków 1977).

38 Trudno określić dominujący u Głowińskiego styl odbioru (ponownie czerpiemy z terminologii pisarza-badacza) poezji Gałczyńskiego. Niechęć i nieliczne, krytyczne uwagi mogą wskazywać na styl ekspresyjny i instrumentalny jako przeważające. Ograniczony materiał badawczy uniemożliwia jednak jednoznaczną klasyfikację. 
obnażającej mechanizmy słowne propagandy oraz tkwiący tam rzekomo język nienawiści. Nie tylko doskwiera tego typu analiz w dorobku naukowym, krytyce literackiej, ale też $\mathrm{w}$ prozie autora Carskiej filiżanki ${ }^{39}$, powstałej w większości już po upadku Polski Ludowej. Gałczyński spełnia wszelkie warunki, aby znaleźć się w kręgu zainteresowań badawczych Głowińskiego. Czy to, że jest jednak w tej przestrzeni tematycznej nieobecny, można tłumaczyć tylko niechęcią? Zapewne zdania w tej sprawie byłyby wśród badaczy literatury podzielone. Nie mamy - jakby sam Głowiński powiedział - wystarczających danych, by jednoznacznie odpowiedzieć. Być może badacz ma problem z odbiorem twórczości Gałczyńskiego. Być może dlatego właśnie zachowuje powściągliwość w publicznym głoszeniu jednoznacznie wrogich opinii.

Źródłem problemu z recepcją dorobku Gałczyńskiego (prócz poezji, publicystyki, satyry) jest jego tematyczna rozpiętość. Ten sam poeta, który tworzy satyryczne, pełne socrealistycznej propagandy utwory, w sposób niezwykle subtelny, intymny potrafi pisać o wielkiej gwieździe, odbitej w małym lusterku gdzieś w leśniczówce Pranie ${ }^{40}$. Zdaje się on rozdarty między pełnym napięć, walki ideowej, burzliwym historycznie światem zewnętrznym a wewnętrznymi potrzebami artystycznymi, ujście którym daje w licznych tekstach. Nie tylko potwierdzają one jego talent. Przede wszystkim są wyrazem impulsywnej i sentymentalnej zarazem emocjonalności. W ten sposób - posłużmy się metaforyką ze świata muzyki - dwa odmienne instrumenty tworzyć mogą jedną, harmonijną pieśń liryczną.

39 W szkicach jak też wspomnianej opowieści autobiograficznej Głowiński nie raz pisze o swoich oponentach, ludziach zasługujących z różnych względów na krytykę. Piętnuje ich przywary, ironizując, często posługując się przy tym pseudonimami takimi jak Pan January. Należy zaznaczyć, że są to przeważnie uogólnienia (jak wskazuje nazwa gatunku - charaktery), portrety krytyczne na podstawie pewnych wzorców, zob. M. Głowiński, Pamięć i charaktery, z M. Głowińskim rozm. S. Bereś, „Odra” 2001, nr 4, s. 63. Swoją drogą, pewne cechy, poza samym przezwiskiem (przypomnijmy, Gałczyński urodził się w styczniu), wskazują na tożsamość jego i Gałczyńskiego, lecz z tekstów (Fanatyk, Nienawidzić siebie, nienawidzić innych) wynika, że Pan January jest osobą współczesną, zob. M. Głowiński, Fanatyk, [w:] tegoż, Przywidzenia i figury. Małe szkice 1977-1997, Kraków 1998, s. 119-120 oraz M. Głowiński, Nienawidzić siebie, nienawidzić innych, [w:] tegoż, Fabuly przerwane. Małe szkice 1998-2007, Kraków 2008, s. 171-172.

40 Zob. K. I. Gałczyński, W leśniczówce, [w:] tegoż, Wybór poezji, wyd. V, oprac. M. Wyka, Wrocław 1982, s. 277. 
Gałczyński udowadnia, że jeden poeta może jednocześnie wzruszać i wywoływać skrajną niechęć. Oczywiście, wynika to ze wspomnianego rozmachu artystycznego poety, z miejscami skrajnie odmiennych językowych obrazów świata, jakie on buduje. Może to jednak brać się również z różnicy doświadczeń, stopnia wrażliwości, otwartości umysłowej odbiorców tej poezji. Czy możemy jednak w tym miejscu postawić kropkę w naszych rozważaniach?

Do każdego twórcy trzeba podchodzić ostrożnie, z podejrzliwością, bacznie obserwując słowa, ale też to, co między słowami zaszyfrowane. Analiza tekstu lirycznego powinna charakteryzować się przenikliwością, która zakłada wiedzę wykraczającą poza tekst. Znajomość kontekstu jest tutaj podstawą. Ale czy tylko w taki sposób należy poezję odczytywać, skradając się do niej ostrożnie? Czy nie zdarza się nam bawić tekstem poetyckim niczym układanką, zagadką, której wyjaśnienie dopuszcza również pewną dziecięcą naiwność i wiarę w moc twórczą wykraczającą poza interesy, ideologie, moc twórczą nadającą życiu sens?

Szanując opinię Michała Głowińskiego, jednocześnie uważam, że „poetatrubadur" miewa w swojej poezji fragmenty prawdziwie zaczarowane i tajemnicze. W późnym okresie twórczości „Zielonego Konstantego” zauważalny jest wyraźny sentymentalizm, melancholia, refleksja nad własnym życiem i zbliżającym się kresem. W szkicach wiersza Księżyc można odnaleźć fragment: „,...] Lecz ty będziesz spała. Ja u szyby/ w kształt księżyca na wieki zaklęty,/ tylko promień wbiję w manuskrypty,/ ponaprawiam w wierszach wszystkie błędy"41. O jakich błędach może być tutaj mowa?

We wspomnianej już leśniczówce Pranie - Muzeum im. Konstantego Ildefonsa Gałczyńskiego, którego opiekunami są Wojciech i Jagienka Kassowie, w jednej z gablot, na lekko już pożółkłej kartce - zapisane charakterystycznym, zielonym atramentem - widnieją słowa: „KRONIKA OLSZTYŃSKA”, a pod nimi:

I

Gdy trzcina zaczyna płowieć,

A żołądź większy w dąbrowie,

Znak, że lata złote nogi

41 Zob. K. Gałczyńska, Zielony Konstanty, czyli opowieść o życiu i poezji Konstantego Ildefonsa Gałczyńskiego, Warszawa 2000, s. 327. 


\author{
Już się szykują do drogi \\ Lato, jakże cię ubłagać, \\ Prośbą jaką? łkaniem jakim? \\ Tak ci pilno pójść i zabrać \\ W walizce zieleń i ptaki? \\ Ptaków tyle. Zieleni tyle \\ Lato, zaczekaj chwilę. \\ II \\ Dobrze jest nad jeziorem \\ Nawet porą deszczową. \\ Leśniczy wieczorem \\ lampę zapala naftową [...]
}

Chciałoby się dodać: „Jeszcze tyle byłoby do pisania [... ${ }^{’ 42}$.

\title{
Bibliografia:
}

Bieńkowski W., O K. I. Gałczyńskim: wspomnienia i refleksje, „Przegląd Kulturalny” 1960, $\mathrm{nr} 31$.

Gałczyńska K., Zielony Konstanty czyli opowieść o życiu i poezji Konstantego Ildefonsa Gałczyńskiego, Warszawa 2000.

Gałczyński K. I., Do Przyjaciół z „Prosto z Mostu”, „Prosto z Mostu” 1936, nr 21.

Gałczyński K. I., Liryka. 1926-1953, red. A. Miedzyrzecki, Warszawa 1973.

Gałczyński K. I., Wybór poezji, wyd. V, oprac. M. Wyka, Wrocław 1982.

Głowiński M., Fabuły przerwane. Małe szkice 1998-2007, Kraków 2008.

Głowiński M., Kręgi obcości. Opowieść autobiograficzna, Kraków 2010.

Głowiński M., Literackość muzyki - muzyczność literatury, [w:] tegoż, Prace wybrane tom II: Narracje literackie i nieliterackie, Kraków 1997, s. 189-206.

42 K. I. Gałczyński, Kronika olsztyńska, [w:] tegoż, Liryka. 1926-1953, red. A. Międzyrzecki, Warszawa 1973, s. 168. 
Głowiński M., Literatura wobec nowomowy, [w:] tegoż, Prace wybrane tom II: Narracje literackie i nieliterackie, Kraków 1997, s. 247-264.

Głowiński M., Pamięć i charaktery, z M. Głowińskim rozm. S. Bereś, „Odra” 2001, nr 4, s. 60-66.

Głowiński M., Przywidzenia i figury. Małe szkice 1977-1997, Kraków 1998.

Głowiński M., Rytuał i demagogia. Trzynaście szkiców o sztuce zdegradowanej, Warszawa 1992.

Głowiński M., Skrzydła i pięta, Kraków 2004.

Głowiński M., Słowo i pieśń (Leśmiana poezja o poezji), [w:] tegoż, Zaświat przedstawiony. Szkice o poezji Bolesława Leśmiana, Warszawa 1981.

Głowiński M., Style odbioru. Szkice o komunikacji literackiej, Kraków 1977.

Głowiński M., Okopień-Sławińska A., Sławiński J., Zarys teorii literatury, Warszawa 1975.

Głowiński M., Wołowiec G., Czas nieprzewidziany. Długa rozprawa bez pana, wójta i plebana, z M. Głowińskim rozm. G. Wołowiec, Warszawa 2018.

Jastrun M., Dziennik 1955-1981, Kraków 2002.

Ligęza W., Muzyka jako święto w liryce Konstantego Ildefonsa Gałczyńskiego, [w:] Dzieło i życie Konstantego Ildefonsa Gałczyńskiego, t. 1, red. A. Kulawik, J. S. Ossowski, Kraków 2005, s. 89-103.

Matuszewski R., Mistrz pur-nonsensu, „Rocznik Towarzystwa Literackiego im. Adama Mickiewicza" 2003, nr 38, s. 31-33.

Miłosz Cz., Zniewolony umyst, Kraków 1999.

Wspomnienia o K. I. Gałczyńskim, przedm. i red. A. Kamieńska, J. Śpiewak, Warszawa 1961.

Wyka K., Poeta i partyjnictwo, [w:] tegoż, Rzecz wyobraźni, Warszawa 1977. 